\title{
LITERATURE REVIEW: THE EFFECTIVENESS OF GIVING GINGER (ZINGIBER OFFICINALE ROSCOE) TO PREGNANT WOMEN NAUSEA VOMITING $1^{\text {st }}$ TRIMESTER PREGNANCY
}

\section{Rr.Catur Leny Wulandari, Mahayu Ciptaning Mulia}

Sultan Agung Islamic University

E-mail: caturleny@unissula.ac.id, mahayu.cipta01@gmail.com

\begin{tabular}{|c|c|}
\hline ARTICLE INFO & ABSTRACT \\
\hline $\begin{array}{l}\text { Received: } \\
\text { July, 24th } 2021 \\
\text { Revised: } \\
\text { August, 17th } 2021 \\
\text { Approved: } \\
\text { August, 19th } 2021\end{array}$ & $\begin{array}{l}\text { Nausea and vomiting often occur when you wake up in the } \\
\text { morning, which is also called morning sickness. Nausea and } \\
\text { vomiting that occur in the first trimester of pregnancy are } \\
\text { caused by increased levels of the hormone Estrogen and } \\
\text { Human Chorionic Gonadotropine (HCG) in serum from the } \\
\text { placenta and can cause a decrease in appetite so that there is } \\
\text { a change in electrolyte balance with potassium, calcium and } \\
\text { sodium which causes changes in body metabolism. Nausea } \\
\text { and vomiting during pregnancy affects about 80-90\% of } \\
\text { pregnant women. Ginger (Zingiber officinale Roscoe) is the } \\
\text { most widely used herbal therapy in the management of } \\
\text { nausea and vomiting. The purpose of this study was to } \\
\text { determine how effectiveness ginger was in reducing the } \\
\text { frequency of nuesea and vomiting in pregnant women in the } \\
\text { 1st trimester.This study uses a literature study method } \\
\text { obtained through electronic media with keywords. There } \\
\text { were } 8 \text { selected articles, consisting of } 5 \text { international and } 3 \\
\text { national articles. This article provides information about the } \\
\text { effectiveness of giving ginger to reduce the frequency of } \\
\text { nausea and vomiting in pregnant women in the 1st trimester. } \\
\text { The conclusions obtained from the analysis are that ginger } \\
\text { can reduce nausea and vomiting in pregnant women in the } \\
\text { 1st trimester. }\end{array}$ \\
\hline
\end{tabular}

Rr.Catur Leny Wulandari, Mahayu Ciptaning Mulia. (2021) Literature Review: The Effectiveness of Giving Ginger (Zingiber Officinale Roscoe) to Pregnant Women Nausea Vomiting 1st Trimester Pregnancy. Journal Eduvest. 1(8): 803-809

How to cite:

E-ISSN:

Published by: 


\section{Rr.Catur Leny Wulandari, Mahayu Ciptaning Mulia}

\begin{tabular}{lll}
\hline KEYWORDS & Nausea Vomiting, Ginger, Pregnancy \\
\hline (c) (i) () & This work is licensed under a Creative Commons \\
\hline
\end{tabular}

\section{INTRODUCTION}

Pregnancy is a continuous chain process consisting of ovulation, migration of spermatozoa and ova, conception, growth of the zygote, nidation (implantation) in the uterus, formation of the placenta and growth and development of the products of conception until term (Jayanti, 2020). The duration of pregnancy lasts until delivery at term (quite months) which is about 280 to 300 days.

The initial phase of pregnancy is called the first trimester which starts from conception to the 12th week of pregnancy. System changes in the mother's body during pregnancy require an adaptation, both physical and psychological (Rahmawati, Rosyidah, \& Marharani, 2016). Not infrequently mothers will experience discomfort in these changes, so prevention and treatment need to be given. If it is not handled wisely, it can trigger discomfort, one of which is nausea and vomiting, therefore concrete information is needed on how to deal with discomfort during the first trimester of pregnancy.

According to BPPSDMK. Ministry of Health RI. 2016 the complaint of nausea and vomiting is a physiological adaptation which means it is a very natural thing to happen, but this needs to be addressed immediately. In a small percentage of pregnancies $(0.2 \%$ $5 \%$ ) continuous and excessive nausea and vomiting resulting in dehydration, electrolyte imbalance and weight loss is often referred to as (Hypermesis Gravidarum). Nausea and vomiting during pregnancy ranks highest among common complaints in the early weeks of pregnancy or Trimester 1 . About $80-90 \%$ of pregnant women experience nausea and vomiting and usually appears at 4-9 weeks of gestation, and reaches its peak in 7 weeks. 12 weeks, and will subside at week 16.

The cause of nausea and vomiting is not known for certain, but it may be due to some combination of the many physical changes in early pregnancy such as the Human Cjoironic Gonadotropin (HCG) hormone which increases slowly in early pregnancy, the rapid increase in the hormone estrogen which is thought to also trigger nausea, and some Pregnant women have a digestive system that is very sensitive to changes in early pregnancy (Papat Patimah, Suhendar Sulaeman, n.d.). Most pregnant women who experience nausea and vomiting only understand that nausea and vomiting felt by pregnant women can only be overcome with the use of drugs, on the contrary, the use of drugs in pregnant women greatly affects the fetus being conceived (Viljoen, Visser, Koen, \& Musekiwa, 2014).

Nausea and vomiting cause decreased appetite and changes in electrolyte balance associated with changes in body metabolism. According to (Rahingtyas, 2008), as many as $80 \%$ of pregnant women who experience nausea and vomiting occur in the first trimester of pregnancy and $2 \%$ of pregnant women in the 1st trimester experience severe nausea and vomiting problems that require medical treatment (Parwitasari, 2009). Nausea in early pregnancy can be reduced by using complementary therapies, including herbal or traditional plants that can be done and are easily available such as ginger, peppermint leaves, lemon, etc (Somoyani, 2020).

Ginger can be trusted to help overcome nausea and vomiting by stimulating digestive tract mortality, and stimulating the secretion of saliva, bile and gastric secretions. Ginger has properties that can be used by pregnant women to reduce the frequency of nausea and vomiting (Djanah, Hadisaputro, \& Hardjanti, 2014). The active 
substances contained in ginger include gingerols, shoagols, glanolactone and terpenoids (Murti \& Darussalam, 2019). The purpose of this study was to determine whether ginger consumption was effective in reducing nausea and vomiting discomfort in pregnant women in the 1 st trimester.

In another study Putri, Ayu (2017) regarding the effectiveness of giving warm ginger in reducing the frequency of nausea and vomiting in first trimester pregnant women, it was found that the results showed that the average frequency of nausea and vomiting before giving warm ginger drinks was 13 times and after decreased to 3.18 times. The test results showed that warm ginger drink was effective in reducing nausea and vomiting in pregnant women $(\mathrm{p}=0.000)$. Based on the results of research by Iluh Meta Indrayani, et al. (2017) the results of bivariate analysis using the Independent Sample T-test, showed that there was a difference in the average frequency of nausea and vomiting in pregnant women in the 1st trimester before and before offering ginger wedang of 2.45 with $\mathrm{p}$ value $=0.000$. So that we can present ginger wedang which is effective in reducing nausea and vomiting in first trimester pregnant women in North Bengkulu Regency in 2017.

The results of this study are also in accordance with the theory of Tiran (2015), nausea and vomiting is one of the earliest, most common and most stressful symptoms associated with pregnancy. Nausea and vomiting are often overlooked because they are considered a normal consequence of early pregnancy without acknowledging the severe impact it has on women and their families. For some women, symptoms may last all day, or may not occur at all upon waking in the morning. Nausea and vomiting during pregnancy are usually caused by changes in the endocrine system that occur during pregnancy, mainly due to high fluctuations in HCG (human chorionic gonadotrophin) levels, in particular because the most common period of gestational nausea or vomiting is in the first 12-16 weeks, which in At that time, HCG reached high levels.

\section{RESEARCH METHODS}

In this study, literature searches were carried out through the media, the Indonesian Ministry of Health, regional databases, google scholars, and Link Springer. The reference lists of retrieved papers were also searched for additional manuscripts. Search terms were not limited by a specific timeframe. Search terms were broad so as to ensure all relevant manuscripts were captured. Studies included in this review were written in English.

The purpose of this article is to determine the effectiveness of ginger consumption on reducing nausea and vomiting in pregnant women in the 1st trimester. The method used to search for articles using English and Indonesian that are relevant to the topic. The search was done through Google Scholar. The keywords used are "Nausea and Vomiting", "Pregnancy", "Ginger". The articles obtained are 8 articles consisting of 5 international articles and 3 national articles which will then be reviewed.

Research conducted by (Murti \& Darussalam, 2019) entitled "The Influence of Sari Ginger Drinking on the Reduction of Gravidarum Emregency Frequency in Trimester I and II Pregnant Mother in BPM Eni Marfuah Samarinda in 2018". The type of research used is quantitative research, namely Pre Experimental with One Group PrePost Test Desigen research design which is carried out on pregnant women with nausea and vomiting in the 1 st and 2 nd trimesters. The technique used in sampling is consecutive sampling. The population in this study were 34 people and the number of respondents was 24 people. The variables in this study were divided into two categories, namely the independent variable: the effect of giving ginger juice and the dependent variable: the 


\section{Rr.Catur Leny Wulandari, Mahayu Ciptaning Mulia}

frequency of nausea and vomiting in pregnant women in the first and second trimesters. The instrument used was an observation sheet containing the frequency of nausea and vomiting on the first day before the intervention. And secondary data in the form of reports of pregnant women 


\section{Rr.Catur Leny Wulandari, Mahayu Ciptaning Mulia}

experiencing nausea and vomiting at BPM Eni Marfuah. Based on the results of the study, it was found that there was an effect of giving ginger juice to the frequency of nausea and vomiting in pregnant women in the first and second trimesters before and after treatment with $\mathrm{p}$-value $=0.000$ or less than $(0.05)$.

Research conducted by (Putri, Haniarti, \& Usman, 2017) entitled "The Effectiveness of Giving Warm Ginger in Reducing the Frequency of Nausea and Vomiting in First Trimester Pregnant Women". This study uses a pre-experimental research design that is one group pretest-posttest. . The research instrument used an interview guide in the form of a questionnaire. The population in this study were all pregnant women with gestational age $<12$ weeks, totaling 34 people. The sampling technique used was total sampling, as many as 34 people. The results showed that the average frequency of nausea and vomiting before being given a warm ginger drink was 13 times and after being given it decreased to 3 times. Bivariable test results showed that warm ginger drink was effective in reducing morning sickness in pregnant women $(\mathrm{p}=0.000)$.

The results of research conducted by (Shawahna \& Taha, 2017) entitled "Which potential harms and benefits of using ginger in the management of nausea and vomiting of pregnancy should be addressed? a consensual study among pregnant women and gynecologists". In this study using the Delphi technique, this technique was used to reach consensus on a core list of the dangers and benefits of using ginger in the management of nausea and vomiting. The Delphi process is followed in two panels in parallel sessions. One panel was followed by 50 obstetricians and other doctors who frequently consulted with pregnant women who suffered from nausea and vomiting and another panel consisted of 50 pregnant women who experienced nausea and vomiting. Based on the results of the study, the benefits and dangers of using ginger for pregnant women should be consulted in advance whether pregnant women can consume ginger or not according to the mother's condition. But on average pregnant women who experience effective nausea and vomiting are reduced when given ginger.

Research conducted by (Kustriyanti \& Putri, 2019) entitled "The Effect of Ginger and Lemon Aromatherapy on Nusa and Vomiting Among Pregnant Women". This study used a randomized controlled trial. The sample used pregnant women with sample criteria of 16 weeks of gestation, mild to moderate nausea and vomiting, singleton pregnancy and no history of other diseases. Respondents were 90 pregnant women. The results showed the effectiveness of ginger and lemon essential oils in experiencing nausea and vomiting.

Research from (Saberi, Sadat, Abedzadeh-Kalahroudi, \& Taebi, 2014) with the title "Effect of Ginger on Relieving Nausea and Vomiting in Pregnancy: A Randomized, Palacebo-Controlled Trial" used 120 eligible pregnant women as respondents. Data were collected using the Rhodes index and analyzed using the ANCOVA test (Covariance test), Kruskal-Wallis, Chi-Square, and Fisher ANCOVA tests showed a significant difference in the mean scores after intervention in the three groups $(\mathrm{P}<0.001)$. The results obtained from this study are that ginger is effective in relieving mild to moderate nausea and vomiting in pregnant women with symptoms of nausea and vomiting with gestational ageless than 16 weeks.

This research was conducted by (Kundarti, Rahayu, \& Utami, 2017) with the title "The Effectiveness of Giving Ginger Powder (Zingiber Officinale) Against the Levels of Nausea and Vomiting in Pregnant Women". This study uses a quasi-experimental design or quasi experiment. The population of pregnant women aged 0-16 weeks who experienced nausea and vomiting was 26 people. The number of research samples was 24 people. The sample was divided into 2 groups, namely the treatment group of 12 people and the control group of 12 people. The sampling technique used is multi-stage sampling. 


\section{Rr.Catur Leny Wulandari, Mahayu Ciptaning Mulia}

The first sampling technique used is cluster sampling and the second sampling technique uses systematic sampling. There is a difference in the effect of ginger on reducing the degree of nausea and vomiting in pregnant women aged 0-16 weeks who were given ginger powder and not given ginger powder.

Research conducted by (Soa, Amelia, \& Octaviani, 2018) with the title "Comparison of the Effectiveness of Giving Decoction of Red Ginger and Mint Leaves with Lime and Honey Against Nausea and Vomiting in Pregnant Women in the 1st Trimester of Waepana Public Health Center, Ngada, NTT". This study uses a Quasi Experiment method with a pretest-posttest approach with a two experimental design. The population in this study were all 35 pregnant women in the first trimester at the Waepana Health Center. Sampling using the formula Lameshow 1990 then get a sample of 11 people each treatment. This study uses purposive sampling with inclusion criteria. Analysis of the data used is univariate and bivariate analysis. The results of this study obtained a comparison between the groups of giving boiled red ginger and mint leaves with lime and honey concluded that the administration of red ginger and mint leaves was more effective than lime and honey.

The results of research conducted by (Saberi, Sadat, Abedzadeh-Kalahroudi, \& Taebi, 2014) with the title "Acupressure and Ginger to Relieve Nausea and Vomiting in Pregnancy: a Randomized Study". This study used a randomized study technique with a total of 159 pregnant women as respondents with predetermined terms and conditions. Data were collected using the Rhodes index and analyzed using the ANOVA, KruskalWallis, Chi-Square, and Fisher tests. The results obtained from this study are that ginger is more effective than acupressure to relieve mild to moderate nausea and vomiting in pregnant women with symptoms of nausea and vomiting with gestational age less than 16 weeks.

\section{RESULTS AND DISCUSSION}

From the results of the literature review that has been presented. There is a difference in the frequency of nausea and vomiting before and after being given ginger. The effect of ginger consumption on pregnant women with nausea and vomiting is effective in addition to analgesic drugs. Of the eight journals used experimental methods. The results of the study - the average nausea and vomiting before the treatment was given ginger to be consumed was on a medium scale but after being given the treatment the results were reduced nausea and vomiting. Ginger contains essential oils of Zingiberena (zingirona), zingiberol, bisabilena, curcumin, gingerol, flandrena, vitamin A and bitter resin which can block serotonin and are believed to be able to give a feeling of comfort in the stomach so that it can overcome nausea.

Ginger is a plant with a million properties that have been known for a long time. Ginger is an important spice. The rhizome has many benefits, including as a spice for cooking, drinks, and candy and is also used in traditional medicinal herbs. The first advantage of ginger is that it contains essential oils that have a refreshing effect and block the gag reflex, while gingerol can smooth the blood and nerves work well. The result is tension can be melted, head so fresh, nausea and vomiting was suppressed. The fragrant aroma of ginger is produced by essential oils, while its oleoresis causes a spicy taste that warms the body and sweats. Some research results show that ginger is a therapeutic ingredient to relieve and reduce nausea and vomiting. In addition, ginger is also effective in reducing emesis gravidarum in pregnant women in the first trimester of pregnancy and reducing nausea and vomiting in multigravida mothers.

This is supported by research by Parwitasari (2014), with the title Comparison of 
the effectiveness of giving boiled red ginger and mint leaves on nausea and vomiting in first trimester pregnant women at Garuda Health Center. The results showed that Characteristics of respondents are 20-35 years (96.7\%), Minang (43.3\%), education Last SMA $(60.0 \%)$, intensity of nausea degree vomiting in the moderate category $(46.6 \%)$. Giving ginger decoction to pregnant women in the third trimester 1 intensity reduces the degree of nausea and vomiting with an average difference of 0.87 and based on Mann Withney test results show that there are difference signifying after administration ginger stew with p-value $(0.001)<(0.05)$, in the mint leaf group obtained p-value $(0.028)>$ $(0.05)$ so that the mandate is not there is a significant difference after offering mint leaf stew. Ratio before between giving ginger stew and mint leaves get the mean rank that is in the ginger group resulted in an exchange difference of 9.87 while mint leaves 6.66 , so it can The word that offering ginger stew is more effective than mint leaves.

\section{CONCLUSION}

Conclusions based on the analysis that has been done by the author, it can be concluded that the use of ginger is effective for reducing nausea and vomiting in pregnant women. Suggestions for carrying out the next literature review should use articles with a set search year, namely the last five years and more databases so that the literature is more updated. In the literature of this study, there was a decrease in nausea and vomiting after being given treatment using ginger in pregnant women. Suggestions for pregnant women who experience nausea and vomiting can consume ginger as an alternative medicine to reduce nausea and vomiting. Because ginger is rich in benefits that can be used and safe for pregnant women.

\section{REFERENCES}

Djanah, Nur, Hadisaputro, Suharyo, \& Hardjanti, Triana Sri. (2014). Pengaruh Akupresur Perikardium 6 Terhadap Mual Muntah Kehamilan Kurang 16 Minggu. Jurnal Kesehatan Ibu Dan Anak, 5(1), 88-95.

Jayanti, Putu Yuliantari. (2020). Gambaran Asuhan Keperawatan Pada Ibu Hamil Dengan Perfusi Perifer Tidak Efektif Oleh Karena Anemia. Poltekkes Denpasar Jurusan Keperawatan.

Kundarti, Finta Isti, Rahayu, Dwi Estuning, \& Utami, Reni. (2017). Efektifitas Pemberian Serbuk Jahe (Zingiber Officinale) Terhadap Tingkatan Mual Muntah Pada Ibu Hamil. Jurnal Ilmu Kesehatan, 4(1), 18-30.

Kustriyanti, Dwi, \& Putri, Arista Adityasari. (2019). The Effect Of Ginger And Lemon Aromatherapy On Nausea And Vomiting Among Pregnant Women. Jurnal Keperawatan Soedirman, 14(1), 15-22.

Murti, Ni Nyoman, \& Darussalam, Handry. (2019). The Influence Of Sari Ginger Drinking On The Reduction Of Gravidarum Emregency Frequency In Trimester I And Ii Pregnant Mother In Bpm Eni Marfuah Samarinda In 2018. Sciences (Irjpms), $3(1), 40-44$.

Papat Patimah, Suhendar Sulaeman, Idriani. (N.D.). Pengaruh Minum Daun Mint, Berjemur Sinar Matahari Dan Kombinasi Terhadap Mual Dan Muntah Pada Ibu Hamil Trimesteri Di Wilayah Kerja Puskesmas Cibeber Kabupaten Cianjur Jawa Barat Tahun 2018.

Parwitasari, Chatur Dhian. (2009). Perbandingan Efektivitas Pemberian Rebusan Jahe Dan Daun Mint Terhadap Mual Muntah Pada Ibu Hamil. Riau University. 
Rr.Catur Leny Wulandari, Mahayu Ciptaning Mulia 
Putri, Ayu Dwi, Haniarti, H. N. I., \& Usman, U. S. N. (2017). Efektifitas Pemberian Jahe Hangat Dalam Mengurangi Frekuensi Mual Muntah Pada Ibu Hamil Trimester I. Prosiding Seminar Nasional Ikakesmada "Peran Tenaga Kesehatan Dalam Pelaksanaan Sdgs," 99-105. Fakultas Kesehatan Masyarakat Universitas Ahmad Dahlan.

Rahingtyas, Devita Kusuma. (2008). Pemanfaatan Jahe (Zingiber Officinale) Sebagai Tablet Isap Untuk Ibu Hamil Dengan Gejala Mual Dan Muntah.

Rahmawati, Nur Aini, Rosyidah, Titin, \& Marharani, Andrya. (2016). Hubungan Pelaksanaan Senam Hamil Dengan Ketidaknyamanan Ibu Hamil Trimester Iii Di Bidan Praktek Mandiri Supadmi, Kunden Bulu, Sukoharjo. Involusi Jurnal Ilmu Kebidanan, 7(12).

Saberi, Farzaneh, Sadat, Zohreh, Abedzadeh-Kalahroudi, Masoumeh, \& Taebi, Mahboobeh. (2014). Effect Of Ginger On Relieving Nausea And Vomiting In Pregnancy: A Randomized, Placebo-Controlled Trial. Nursing And Midwifery Studies, 3(1).

Shawahna, Ramzi, \& Taha, Assim. (2017). Which Potential Harms And Benefits Of Using Ginger In The Management Of Nausea And Vomiting Of Pregnancy Should Be Addressed? A Consensual Study Among Pregnant Women And Gynecologists. Bmc Complementary And Alternative Medicine, 17(1), 1-12.

Soa, Ursula Orcena Mau, Amelia, Rizky, \& Octaviani, Dhita Aulia. (2018). Perbandingan Efektivitas Pemberian Rebusan Jahe Merah Dan Daun Mint Dengan Jeruk Nipis Dan Madu Terhadap Mual Muntah Pada Ibu Hamil Trimester I Di Puskesmas Waepana, Ngada, Ntt. Jurnal Kebidanan, 8(2), 157-167.

Somoyani, Ni Ketut. (2020). Literature Review: Terapi Komplementer Untuk Mengurangi Mual Muntah Pada Masa Kehamilan. Jurnal Ilmiah Kebidanan (The Journal Of Midwifery), 8(1), 10-17.

Viljoen, Estelle, Visser, Janicke, Koen, Nelene, \& Musekiwa, Alfred. (2014). A Systematic Review And Meta-Analysis Of The Effect And Safety Of Ginger In The Treatment Of Pregnancy-Associated Nausea And Vomiting. Nutrition Journal, $13(1), 1-14$. 